\title{
PENDIDIKAN KESEHATAN TENTANG KESEHATAN REPRODUKSI REMAJA DI TARUNA SWASTIKA YUWANA, DESA LABAN KULON KECAMATAN MENGANTI KABUPATEN GRESIK
}

DOI: https://doi.org/10.33024/jkpm.v4i5.4114

\section{Veronica Silalahi}

STIKES Katolik St.Vincentius a Paulo Surabaya

Disubmit: 23 Maret 2021 Diterima: 17 April 2021 Diterbitkan: 30 September 2021

Email korespondensi : vero.silalahi30@gmail.com

\begin{abstract}
ABSTRAK
Kesehatan reproduksi remaja adalah suatu kondisi sehat yang menyangkut sistem, fungsi dan proses reproduksi yang dimiliki oleh remaja. Masalah kesehatan reproduksi yang bisa terjadi akibat perilaku berisiko seperti ketidaksiapan menghadapi konflik perkawinan atau aborsi, seks pranikah, kekerasan seksual, penyimpangan perilaku seksual, gangguan kesehatan, penyakit kelamin, kematian yang disebabkan oleh organ reproduksi yang belum matang. Masih tingginya masalah kesehatan reproduksi tersebut dapat dipengaruhi oleh masih kurangnya pengetahuan/pemahaman remaja mengenai kesehatan reproduksi. Pengabdian masyarakat melalui kegiatan pendidikan kesehatan dilakukan secara daring atau online melalui zoom meeting pada 20 responden remaja di Taruna Swastika Yuwana Desa Laban Kulon Kecamatan Menganti, Kabupaten Gresik. Kegiatan pendidikan kesehatan diawali dengan pemberian pre test dan setelah diberikan pendidikan kesehatan, responden diberikan post test melalui google form. Terdapat peningkatan pengetahuan setelah diberikan pendidkan kesehatan. Peningkatan pengetahuan dan pemahaman remaja tentang kesehatan reproduksi, dapat membantu remaja berperilaku sehat dan dapat merubah perilaku menjadi lebih baik.
\end{abstract}

Kata kunci : Pendidikan Kesehatan, Kesehatan Reproduksi Remaja, Remaja

\begin{abstract}
Adolescent reproductive health is a health condition that concerns the reproductive systems, functions, and processes of adolescents. Reproductive health problems can occur due to risky behavior such as unpreparedness to face marital conflicts or abortion, premarital sex, sexual violence, sexual behavior deviations, health problems, venereal diseases, death caused by immature reproductive organs. The high rate of reproductive health problems can be influenced by the lack of knowledge or understanding of adolescents about reproductive health. Community service through health education activities is online by zoom meetings on 20 teenage respondents at Taruna Swastika Yuwana, Laban Kulon Village, Kec. Menganti District, Kab. Gresik. Health education activities begin with giving a pre-test and after being given health education, respondents are given a post-test by a google form. There is an increase in
\end{abstract}


knowledge after being given health education. Increased knowledge and understanding of adolescents about reproductive health, can help adolescents behave healthily and can change behavior for the better

Keywords : Health Educaction, Adolescent reproductive health, Adolescent

\section{PENDAHULUAN}

Taruna Swastika Yuwana Desa Laban Kulon adalah organisasi karang taruna remaja yang berada di Kecamatan Menganti, Kabupaten Gresik. Karang taruna ini merupakan wadah yang memiliki misi untuk membina generasi muda. Adapun visi karang taruna yaitu sebagai wadah pembinaan dan pengembangan kreativitas generasi muda yang berkelanjutan untuk menjalin persaudaraan dan rasa kebersamaan menjadi mitra organisasi lembaga, baik kepemudaan ataupun pemerintah dalam pengembangan kreativitas. Kemampuan dibidang kesejahteraan sosial baik untuk masyarakat dilingkungan sekitar ataupun di wilayah lain. Dalam bidang kesejahteraan sosial, karang taruna sebagai organisasi sosial masyarakat di pedesaan akan ditingkatkan fungsi dan perannya agar dapat menghimpun menggerakkan dan menyalurkan peran serta generasi muda dalam pembangunan. Selain mewujudkan kesejahteraan sosial di desa atau kelurahan, karang taruna berfungsi mengembangkan potensi kreatifitas generasi muda agar secara terarah generasi muda di pedesaan membina dirinya sebagai pendukung pembangunan pedesaan (Ambarsari \& Mardliyah, 2019). Salah satu bentuk kegiatan dari karang taruna Swastika Yuwana Desa Laban Kulon ini adalah pendidikan kesehatan yang memberikan informasi kepada remaja. Remaja Taruna Swastika Yuwana Desa Laban Kulon ini belum pernah diberikan pendidikan kesehatan mengenai kesehatan reproduksi remaja. Pendidikan kesehatan reproduksi remaja ini diberikan untuk meningkatkan pengetahuan remaja tentang kesehatan reproduksi dan mencegah terjadinya hal-hal negatif yang berkaitan dengan reproduksi seperti penyimpangan perilaku seksual, kehamilan tidak diinginkan, aborsi pada remaja, narkoba dan napza (Meilan, 2018)

Kesehatan reproduksi adalah keadaan sehat secara fisik, mental, dan sosial secara utuh, tidak semata-mata bebas dari penyakit atau kecacatan yang berkaitan dengan sistem, fungsi, dan proses reproduksi (Badan Kependudukan Dan Keluarga Berencana Nasional, Badan Pusat Statistik, Kementrian Kesehatan, \& USAID, 2018) Kesehatan Reproduksi Remaja adalah suatu kondisi sehat yang menyangkut sistem, fungsi dan proses reproduksi yang dimiliki oleh remaja. Situasi kesehatan reproduksi remaja dalam data yang disebutkan oleh (Kementrian Kesehatan RI, 2015) bahwa pada tahun 2012 sebanyak 4.5\% remaja laki-laki berusia 15-19 tahun dan 14.6\% remaja berusia 20-24 tahun pernah melakukan seks pra nikah. Dari survey yang sam didapatkan alasan karena penasaran/ingin tahu $(57.5 \%$ pria), terjadi begitu saja (38\% perempuan) dan dipaksa oleh pasangan (12.6\% perempuan). Hal ini menunjukkan bahwa kurangnya pemahaman remaja tentang pengetahuan hidup sehat, resiko hubungan seksual dan kemampuan untuk menolak hubungan yang tidak mereka inginkan. Selain data diatas, disebutkan juga bahwa proporsi kehamilan remaja di Indonesia pada tahun 2013 adalah $0.02 \%$ kehamilan $<15$ tahun, dan $1.97 \%$ kehamilan pada usia 15-19 tahun. 
Pada SDKI 2017 didapatkan data bahwa perilaku pacaran yang dilakukan remaja adalah berpegangan tangan, berpelukan, cium bibir dan meraba atau diraba. Berpegangan tangan dilakukan oleh wanita dan pria sebanyak $64 \%$ dan $75 \%$. Perilaku cium bibir pada pria sebanyak $50 \%$ dan wanita sebanyak $30 \%$, berpelukan $33 \%$ pada pria dan $30 \%$ pada wanita, meraba/diraba pada pria $21 \%$ dan $5 \%$ pada wanita. Data mengenai kehamilan tidak diinginkan menurut SDKI 2017, 12\% wanita melaporkan mempunyai pengalaman kehamilan tidak diinginkan dan $7 \%$ pria melaporkan pasangannya mengalami kehamilan tidak diinginkan. Untuk data pengalaman aborsi diantara teman adalah $23 \%$ wanita tahu seseorang yang aborsi dan $1 \%$ wanita sarankan/pengaruhi teman/seseorang untuk aborsi(Badan Pusat Statistik Kementerian Kesehatan, 2018). Berdasarkan penelitian yang dilakukan oleh Sari, 2014 dalam mengenai bentuk perilaku pacaran remaja yang dilakukan di salah satu SMA di Surabaya didapatkan hasil bahwa sebanyak 90\% berpegangan tangan dengan mesra saat bersama pasangan, 78\% berpelukan, Sebanyak $75 \%$ pernah berciuman, sebanyak $56 \%$ pernah saling meraba bagian sensitif, sebanyak $37 \%$ pernah melakukan petting, sebanyak 33\% pernah oral seks, sebanyak $27 \%$ remaja mengaku sudah pernah melakukan hubungan seksual dengan pasangan

Sampai saat ini masalah kesehatan reproduksi masih menjadi perhatian, karena masih tingginya kejadian akibat kesehatan reproduksi yang tidak dijaga dengan baik. Data dari Badan Koordinasi Keluarga Berencana Nasional / BKKBN), sekitar 23\% tinggi remaja sekolah di Indonesia divonis bahwa mereka telah melakukannya hubungan seksual dan 20\% dari mereka melakukan aborsi (Pakasi dalam Handayani, Wiranti, Raharjo, \& Nugroho, 2019). Para remaja berpikir bahwa berpacaran dapat meningkatkan harga diri mereka. Namun, perilaku pacaran yang tidak sehat dapat memberikan dampak, seperti seks pranikah. Para remaja yang tidak mampu mengelola kesehatan reproduksi dengan baik, maka mereka dapat membuang waktu untuk melakukan aktivitas yang lebih baik seperti bergaul dan berkencan yang sehat. Pada penelitian Gambit, 2000 dalam (Handayani et al., 2019) ketidakmampuan seorang remaja untuk mengatur rangsangan seksual menyebabkan perilaku seksual yang menyimpang. Perilaku berisiko menimbulkan berbagai masalah, seperti ketidaksiapan menghadapi konflik perkawinan atau aborsi, gangguan kesehatan, penyakit kelamin, bahkan kematian yang disebabkan oleh organ reproduksi yang belum matang. Hasil penelitian yang dilakukan oleh (Istiqomah \& Notobroto, 2016) pada remaja SMK di Surabaya, bahwa remaja dengan pengetahuan yang rendah sebanyak $(90,9 \%)$ memiliki perilaku seksual pranikah risiko tinggi dan 10 kali berisiko terpapar perilaku seksual pranikah risiko tinggi. Pada remaja dengan kontrol diri rendah sebanyak $(93,9 \%)$ memiliki perilaku seksual pranikah risiko tinggi dan 46 kali berisiko terpapar perilaku seksual pranikah dengan risiko tinggi

Berdasarkan latar belakang di atas solusi yang bisa digunakan tim pengabdian masyarakat dan mitra adalah memberikan pendidikan kesehatan. Pendidikan kesehatan merupakan suatu proses perubahan pengetahuan yang merubah perilaku dari tidak sehat menjadi sehat oleh seorang edukator kepada orang lain secara individu ataupun kelompok. Penelitian yang dilakukan oleh Johariyah \& Mariati, 2018 pada remaja SMA di Bantul, Yogyakarta, didapatkan bahwa terdapat perbedaan yang dignifikan terhadap perubahan pengetahuan remaja sebelum dan setelah diberi penyuluhan tentang kesehatan reproduksi remaja. Pendidikan 
kesehatan dapat meningkatkan pengetahuan remaja tentang kesehatan reproduksi remaja dan diharapkan nantinya dapat menjaga kesehatan reproduksi remaja (Johariyah \& Mariati, 2018).

\section{MASALAH}

Alasan memilih tempat kegiatan karena di Taruna ini banyaknya kelompok remaja yang perlu diberikan pendidikan kesehatan, dan juga remaja juga sangat riskan sekali dengan perilaku beresiko seksual. Selain itu remaja di Taruna Swastika Yuwana Desa Laban Kulon ini belum pernah diberikan pendidikan kesehatan mengenai kesehatan reproduksi remaja. Tujuan dari pendidikan kesehatan ini adalah untuk meningkatkan pengetahuan remaja tentang kesehatan reproduksi dan mencegah terjadinya hal-hal negatif yang berkaitan dengan reproduksi seperti penyimpangan perilaku seksual, kehamilan tidak diinginkan, aborsi pada remaja, narkoba dan napza.

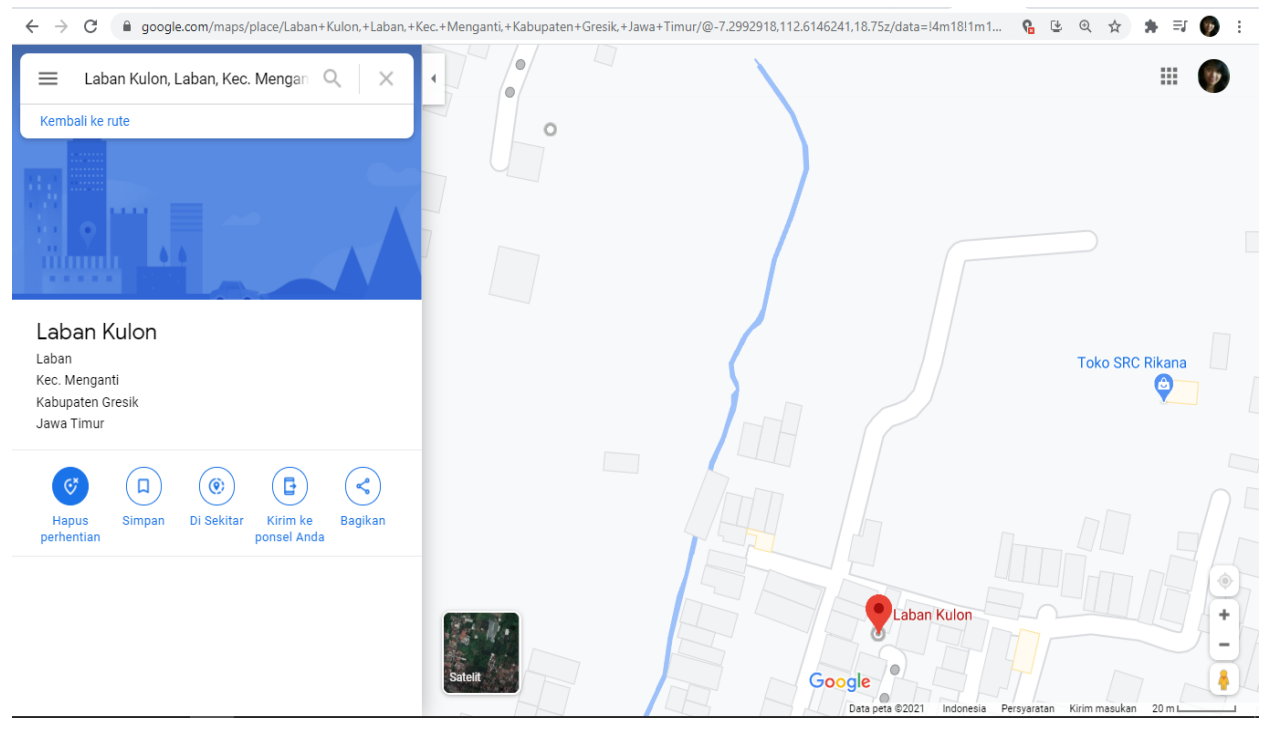

Gambar 2.1 Map Lokasi Kegiatan Pengabdian Kepada Masyarakat

\section{METODE}

a. Tahap Persiapan

Tahap persiapan dimulai dengan observasi tempat pengabdian masyarakat yang dilakukan untuk mendapatkan informasi mengenai program pendidikan kesehatan yang sudah pernah dilakukan dan kebutuhan pendidikan kesehatan yang diperlukan saat ini. Selain itu pada tahap persiapan, dilakukan persiapan pembuatan materi berupa powerpoint, link zoom meeting dan pembuatan google form untuk pre-test dan post-test. Setelah itu ketua pengabdian masyarakat berkoordinasi dengan Ketua PHDI Desa Laban Kulon Kec.Menganti, Kab. Gresik terkait perizinan dan pelaksanaan kegiatan dan koordinator remaja di Taruna untuk membantu mengumpulkan remaja yang tergabung di Taruna Swastika Yuawana untuk membantu mengumpulkan remaja Taruna dan dijelaskan tujuan pelaksanaan kegiatan. 
b. Tahap pelaksanaan

Pendidikan kesehatan dilakukan secara online melalui zoom meeting. Pendidikan kesehatan yang diberikan adalah kesehatan reproduksi remaja.

c. Evaluasi
1) Struktur
Peserta yang hadir dalam kegiatan zoom meeting ada 20 orang. Kegiatan berjalan dengan lancar. Para remaja sangat interaktif saat kegiatan dan banyak yang bertanya. Para remaja juga dapat memahami materi yang diberikan.
2) Proses
Pelaksanaan kegiatan dilakukan pukul 16.00-17.00 WIB sesuai dengan jadwal yang telah direncanakan.

\section{HASIL DAN PEMBAHASAN}

Kegiatan pendidikan kesehatan tentang kesehatan reproduksi remaja dilaksanakan pada tanggal 23 Januari 2021 di Taruna Swastika Yuwana Desa Laban Kulon Kecamatan Menganti Kabupaten Gresik secara daring dengan zoom meeting. Sebelum diberikan pendidikan kesehatan, responden diberikan pre-test melalui google form dan setelah diberikan pendidikan kesehatan, responden juga diberikan kembali post-test dengan link google form yang sama. Tujuannya adalah untuk mengevaluasi tingkat pengetahuan remaja sebelum dan sesudah diberikan pendidikan kesehatan. Metode pendidikan kesehatan dilakukan dengan ceramah, dimana ketua pengabdian masyarakat menyampaikan materi terkait kesehatan reproduksi remaja. Setelah ceramah, dilakukan diskusi dan tanya jawab, dimana responden yang belum paham dan ingin sharing pengalaman dapat disampaikan dan langsung dijawab oleh pemberi materi. Kegiatan pendidikan kesehatan ini menggunakan media powerpoint.

1) Usia responden yang mengikuti kegiatan

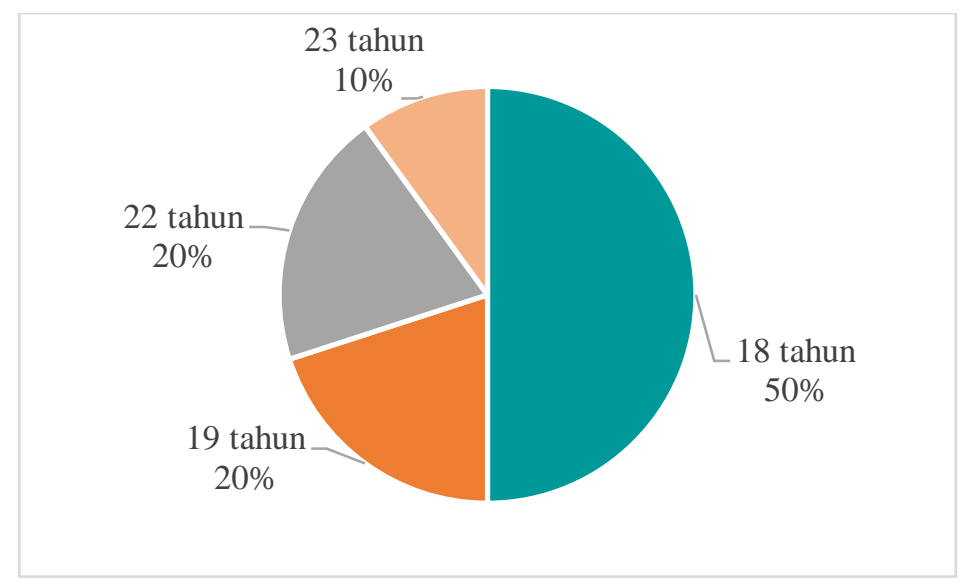

Diagram 1 Usia Responden Mahasiswi Remaja Taruna Swastika Yuana, Desa laban Kulon, Kec. Menganti, Kab.Gresik

Dari diagram diatas, jumlah responden yang berusia 18 tahun sebanyak 10 orang, berusia 19 tahun sebanyak 4 orang, berusia 22 tahun sebanyak 4 orang, berusia 23 tahun sebanyak 2 orang. Ketua pengabdian masyarakat dibantu oleh 
Koordiantor Taruna Swastika Yuana untuk mengumpulkan remaja yang tergabung didalamnya, dan mengkoordinasikan waktu pelaksanaan pendidikan kesehatan yang dilakukan secara daring melalui zoom meeting.

2) Pemberian Pendidikan Kesehatan

Setelah semua responden bergabung dalam zoom meeting, ketua pengabdian masyarakat memberikan penjelasan mengenai kesehatan reproduksi remaja. Setelah penjelasan, dilakukan diskusi dan tanya jawab membahas seputar kesehatan reproduksi remaja dan juga sharing dari remaja.

\section{Kesehatan reproduksi remaja}
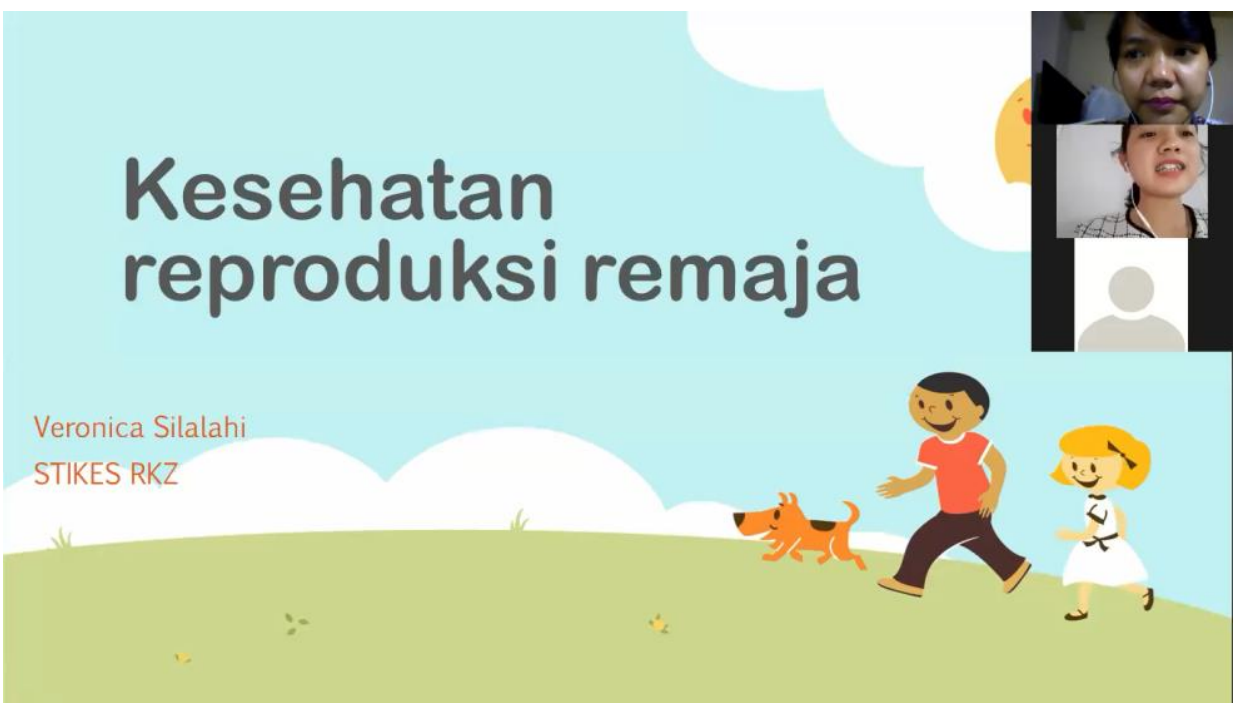

Gambar 4.1 Penjelasan mengenai pendidikan kesehatan kepada responden

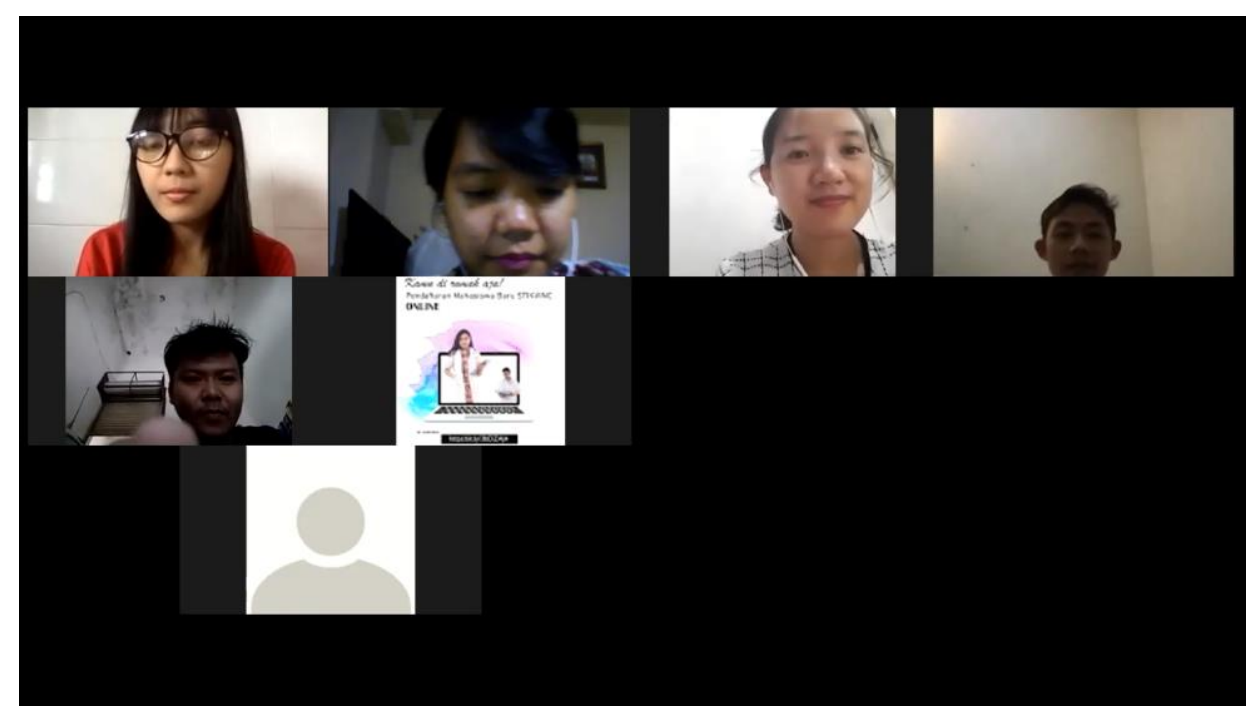

Gambar 4.2 Sesi Diskusi dan Tanya Jawab 
3) Hasil pre-test dan post-test pelaksanaan pendidikan kesehatan

a. Pre-test Sebelum diberikan pendidikan kesehatan

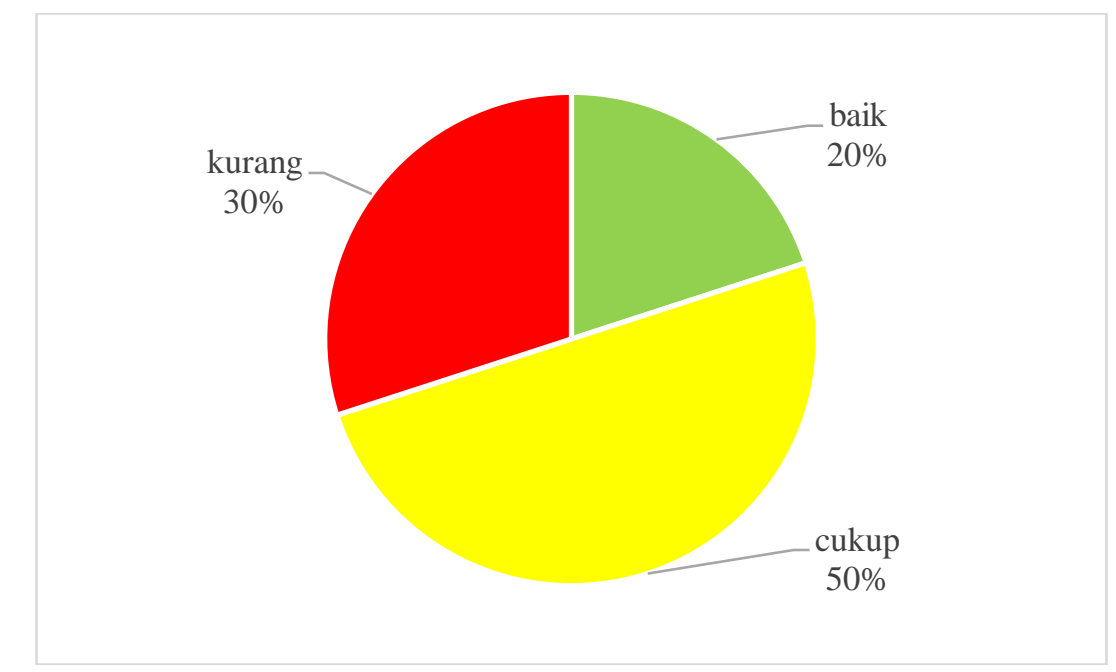

Diagram 2 Pengetahuan sebelum diberikan pendidikan kesehatan tentang kesehatan reproduksi remaja di Taruna Swastika Yuana, Desa laban Kulon, Kec. Menganti, Kab.Gresik

Pengetahuan yang didapatkan pada responden sebelum diberikan pendidikan kesehatan tentang kesehatan reproduksi remaja adalah 50\% (10 responden) responden memiliki pengetahuan cukup, 20\% (4 responden) memiliki pengetahuan baik, dan30\% (6 responden) memiliki pengetahuan kurang.

b. Post-test Setelah diberikan pendidikan kesehatan

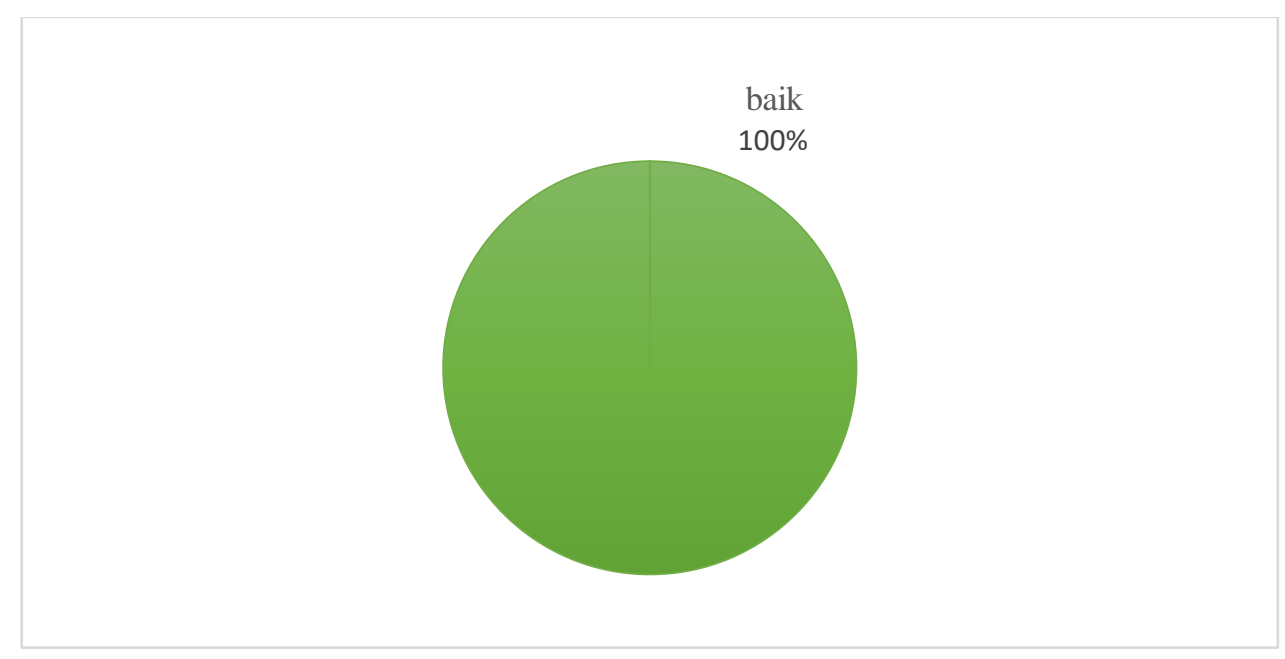

Diagram 3 Pengetahuan setelah diberikan pendidikan kesehatan tentang kesehatan reproduksi remaja di Taruna Swastika Yuana, Desa laban Kulon, Kec. Menganti, Kab.Gresik

Pengetahuan yang didapatkan pada responden setelah diberikan pendidikan kesehatan tentang kesehatan reproduksi remaja adalah 100\% (20 responden) memiliki pengetahuan baik. 
Pendidikan kesehatan yang diberikan pada remaja di Taruna Swastika Yuana, Menganti, Gresik menunjukkan bahwa pendidikan kesehatan sangat baik diberikan untuk memberikan informasi kesehatan yang bermanfaat yang nantinya akan dipraktikkan untuk mencegah terjadinya masalah yang berkaitan dengan kesehatan reproduksi remaja. Pada remaja di Taruna Swastika Yuana diharapkan setelah diberikan pendidikan kesehatan ini dapat menjaga kesehatan reproduksi dan mencegah timbulnya masalah terkait reproduksi, seperti pernikahan usia dini, penyakit menular seksual, HIV/AIDS, pacaran tidak sehat, hubungan seksual pra nikah dan juga bisa menyebarluaskan informasi kesehatan yang didapatkan kepada sesama remaja, maupun kalangan masyarakat lainnya.

\section{KESIMPULAN}

Pelaksanaan kegiatan pengabdian masyatakat dalam bentuk pemberian pendidikan kesehatan dengan sasaran remaja di Taruna Swastika Yuana, Menganti, Gresik dilakukan untuk memberikan informasi kesehatan tentang kesehatan reproduksi remaja. Pendidikan kesehatan ini dapat membantu meningkatkan pengetahuan dan pemahaman remaja tentang kesehatan reproduksi remaja dan dapat berperilaku sehat dan juga dapat merubah perilaku menjadi lebih baik sehingga diupayakan setelah pemberian informasi kesehatan ini, remaja dapat mencegah terjadinya dampak yang tidak baik terkait dengan kesehatan reproduksi remaja

\section{DAFTAR PUSTAKA}

Ambarsari, D. I. A., \& Mardliyah, S. (2019). REVITALISASI KARANG TARUNA UNTUK MENINGKATKAN PARTISIPASI PEMUDA DALAM PEMBANGUNAN DESA DI DESA TRETES KECAMATAN PRIGEN KABUPATEN PASURUAN. JPUS (Jurnal Pendidikan Untuk Semua). Retrieved from https://journal.unesa.ac.id/index.php/jpls/index

Badan Kependudukan Dan Keluarga Berencana Nasional, Badan Pusat Statistik, Kementrian Kesehatan, \& USAID. (2018). Survei Demografi dan Kesehatan Indesia 2017. Jakarta: Badan Kependudukan dan Keluarga Berencana Nasional, 2018.

Badan Pusat Statistik Kementerian Kesehatan. (2018). Survei Demografi dan Kesehatan: Kesehatan Reproduksi Remaja. Jakarta.

Handayani, O. W. K., Wiranti, li., Raharjo, B. B., \& Nugroho, E. (2019). The Reproduction Health Behavior of High School Teenagers in Semarang, Indonesia. The Open Public Health Journal, 12, 309-314. https: / / doi.org/10.2174/1874944501912010309

Istiqomah, N., \& Notobroto, H. B. (2016). Pengaruh Pengetahuan , Kontrol Diri terhadap Perilaku Seksual Pranikah di Kalangan Remaja SMK di Surabaya. Jurnal Biometrika Dan Kependudukan, 5, 125-134. https://doi.org/https://ejournal.unair.ac.id/JBK/article/view/5832/3738

Johariyah, A., \& Mariati, T. (2018). Efektivitas Penyuluhan Kesehatan Reproduksi Remaja Dengan Pemberian Modul Terhadap Perubahan Pengetahuan Remaja. Jurnal Manajemen Kesehatan Yayasan RS.Dr.Soetomo, 4, 38-46. Retrieved from http://jurnal.stikes- 
yrsds.ac.id/index.php/JMK/article/view/100/98

Kementrian Kesehatan RI. (2015). Situasi Kesehatan Reproduksi Remaja. Jakarta. Retrieved from http://www.depkes.go.id/resources/download/pusdatin/infodatin/infoda tin reproduksi remaja-ed.pdf

Meilan, N. (2018). Kesehatan Reproduksi Remaja: Implementasi PKPR dalam Teman Sebaya. Malang: Wineka Media.

Sari, R. T. (2014). Perilaku Seksual Remaja Siswa SMK Ketintang Surabaya. Jurnal BK UNESA, 4, 1-0. Retrieved from https://jurnalmahasiswa.unesa.ac.id/index.php/jurnal-bkunesa/article/view/9118/9069

Ambarsari, D. I. A. , \& Mardliyah, S. (2019). REVITALISASI KARANG TARUNA UNTUK MENINGKATKAN PARTISIPASI PEMUDA DALAM PEMBANGUNAN DESA DI DESA TRETES KECAMATAN PRIGEN KABUPATEN PASURUAN. JPUS (Jurnal Pendidikan Untuk Semua). Retrieved from https://journal.unesa.ac.id/index.php/jpls/index

Badan Kependudukan Dan Keluarga Berencana Nasional, Badan Pusat Statistik, Kementrian Kesehatan, \& USAID. (2018). Survei Demografi dan Kesehatan Indesia 2017. Jakarta: Badan Kependudukan dan Keluarga Berencana Nasional, 2018.

Badan Pusat Statistik Kementerian Kesehatan. (2018). Survei Demografi dan Kesehatan : Kesehatan Reproduksi Remaja. Jakarta.

Handayani, O. W. K., Wiranti, li., Raharjo, B. B., \& Nugroho, E. (2019). The Reproduction Health Behavior of High School Teenagers in Semarang, Indonesia. The Open Public Health Journal, 12, 309-314. https: / / doi.org/10.2174/1874944501912010309

Istiqomah, N., \& Notobroto, H. B. (2016). Pengaruh Pengetahuan , Kontrol Diri terhadap Perilaku Seksual Pranikah di Kalangan Remaja SMK di Surabaya. Jurnal Biometrika Dan Kependudukan, 5, 125-134. https://doi.org/https://ejournal.unair.ac.id/JBK/article/view/5832/3738

Johariyah, A., \& Mariati, T. (2018). Efektivitas Penyuluhan Kesehatan Reproduksi Remaja Dengan Pemberian Modul Terhadap Perubahan Pengetahuan Remaja. Jurnal Manajemen Kesehatan Yayasan RS.Dr.Soetomo, 4, 38-46. Retrieved from http://jurnal.stikesyrsds.ac.id/index.php/JMK/article/view/100/98

Kementrian Kesehatan RI. (2015). Situasi Kesehatan Reproduksi Remaja. Jakarta. Retrieved from http://www.depkes.go.id/resources/download/pusdatin/infodatin/infoda tin reproduksi remaja-ed.pdf

Meilan, N. (2018). Kesehatan Reproduksi Remaja: Implementasi PKPR dalam Teman Sebaya. Malang: Wineka Media.

Sari, R. T. (2014). Perilaku Seksual Remaja Siswa SMK Ketintang Surabaya. Jurnal BK UNESA, 4, 1-0. Retrieved from https://jurnalmahasiswa.unesa.ac.id/index.php/jurnal-bkunesa/article/view/9118/9069 